\section{Organization of Free and Open Source Software Projects: In-between the Community and Traditional Governance}

\author{
Isabela Neves Ferraz ${ }^{1}$ \\ isabelanf@gmail.com | (D) 0000-0001-8536-8418 \\ Carlos Denner dos Santos Júnior ${ }^{1,2}$ \\ carlosdenner@unb.br| (D) 0000-0002-4481-0115
}

\section{ABSTRACT}

This work aimed to understand what community-based free software projects are and what governance characteristics (structure and control) differentiate them from traditional organizations, thus spurring further reflections on this business model. A literature review was conducted to outline the main perceptions on this topic, as well as qualitative exploratory research, involving documentary analysis and interviews with four Brazilian participants who work in the management of projects.. The exploratory research was a preliminary contact with the investigated field to make the arguments presented more reliable. Among the reflections, it is observed that even though it is possible to distinguish community-based free software projects from traditional organizations, a crucial factor not always considered are the transformations resulting from the development of these projects. It is necessary that the studies consider the context of functioning, as well as the changes and interorganizational relationships established by the projects over time. Considering these issues, it is believed that approximations between projects and traditional organizations can occur, even if community characteristics are maintained.

\section{KEYWORDS}

Free Software Projects, Communities, Structure, Control, Governance
${ }^{1}$ SOCIE-DADOS, Universidade de Brasilia, Brasilia, DF, Brasil

${ }^{2}$ LATECE, Universite du Quebec a Montreal, Montreal, QC, Canada

Received: 06/26/2020

Revised: 09/29/2020.

Accepted: 10/19/2020.

Published Online: 04/13/2021.

DOI: http://dx.doi.org/10.15728/bbr.2021.18.3.6 


\section{INTRODUCTION}

The current scenario in which organizations find themselves has enabled the emergence of modern and flexible businesses in response to the complexity and constant changes in the environment (Adler, Heckscher, \& Prusak, 2011; Fjeldstad, Snow, Miles, \& Lettl, 2012; Zebari, Zeebaree, Jacksi, \& Shukur, 2019). In this scenario, organizational arrangements with these characteristics make intensive use of information and communication technologies (ICT) through the interactions of their members in society, as is the case with virtual communities (Faraj, Jarvenpaa, \& Majchrzak, 2011; Seidel \& Stewart, 2011). A widely disseminated example in the scientific and professional literature of entrepreneurship based on the virtual community model are free software projects. These projects are characterized by the availability of the software source code in communities open to the public to receive contributions directed to their improvement (Crowston et al., 2007; Santos Júnior, Kuk, Kon, \& Pearson, 2013; Viseur \& Charleux, 2019). Free software projects are spaces for promoting open innovation that depend heavily on ICT for the operation of communities since work teams are generally geographically distributed (Mäenpää; Munezero, Fagerholm, \& Mikkonen, 2017; Eseryel, Wei, \& Crowston, 2020).

According to investigations on the topic, community-based free software projects have a way of functioning that differs from the traditional perspective of software organization (Panchal, 2010; Lindberg, Berente, Gaskin, \& Lyytinen, 2016; Miscione, Ziolkowsk, Zavolokina, \& Schwabe, 2018). Understanding how communities organize their activities with the intention of achieving the expected results is an important research focus to position these ventures in the organizational literature. Regarding the more bureaucratic forms of organization, communities continue to play a less prominent role, which leads to the need to improve this field of research (O'Mahony \& Ferraro, 2007; O'Mahony \& Lakhani, 2011; Zheng, Zhao, \& Stylianou, 2013). In addition, it is essential that studies better explain how complex and innovative products are developed in community models (Lindberg et al., 2016).

In the area of free software, studies are usually found that portray communities as enterprises whose management stands out due to the minimal use, or absence, of traditional or formal structures and controls (Raymond, 1999; Panchal, 2010; Arazy, Daxenberger, \& Lifshitz -Assaf, 2016; Miscione et al., 2018; Eseryel et al., 2020). Even when they recognize that formalizations can occur due to the maturity achieved, it is common in research that the informal logic of operation (Xu et al., 2005; Latterman \& Stieglitz, 2005; O’Mahony \& Ferraro, 2007), or the perception that it is still necessary to obtain a better understanding of how formal aspects occur in practice stand out (Santos Junior, Kuk, Kon, Suguiura, 2011; Mäenpää et al., 2017; Viseur $\&$ Charleux, 2019).

Therefore, what is noted is that regardless of the development presented, a significant part of the investigations on the subject led to associations in which free software projects are perceived as representatives of the informal logic of the communities' operation. The existence of these visions demonstrates that the scenario of free software ventures still needs to be more clearly understood since they are innovative and competitive businesses that can take on more complex shapes than the ones being portrayed. In addressing these issues, the concept of governance is fundamental, as it involves the means that direct and control individuals in totally or partially autonomous initiatives, such as free software communities (Markus, 2007; Li-Ying \& Salomo, 2013). This concept is characterized by having multiple dimensions involving several principles, practices, and processes found in organizations (Mäenpää et al., 2017; Glass \& Newig, 2019). 
From the context presented, this research intends to contribute to the organizational literature by examining the governance of community-based free software projects from the perspective of the structure and control processes. It is intended to promote the understanding of what the community and informal functioning of these projects would be, differentiating it from the traditional or bureaucratic model of organization. In addition, reflections were also expounded upon that could serve as a basis for future investigations in the area.

The main objective is to answer the following questions: 1) What general and governance characteristics differentiate community-based free software projects from traditional organizations? and 2) What reflections can be made to assist in the preparation of future research on the topic? To achieve this objective, the organizational areas and free software literature were consulted. While preparing this work, the researchers also chose to conduct exploratory research through documentary analysis and interviews with four Brazilians who participate in the management of different free software communities. It is important to highlight that the exploratory empirical research was complementary to the literature review, with the purpose of developing more robust reflections on the proposed theme, so that they can be verified later.

\section{LITERATURE PERSPECTIVES ON COMMUNITY-BASED FREE SOFTWARE PROJECTS}

\subsection{Community-based Free Software Projects}

Community projects are formed by individuals with an interest in opening their productive activities to a wider community (Santos Junior et al., 2013; Seidel \& Stewart, 2011; Eseryel et al., 2020). These projects significantly incorporate voluntary work and are represented by groups whose members work together towards a common goal, which can result in solving a problem, producing a certain innovation, or other new knowledge (Panchal, 2010; Seidel \& Stewart, 2011; O’Mahony \& Lakhany, 2011; Zheng, Zhao, \& Stylianou, 2013; Lindberg et al., 2016; Miscione et al., 2018).

As members of community projects do not necessarily meet in the same physical space, the use of information and communication technologies (ICT) is crucial to the emergence and operation of this architecture (Seidel \& Stewart, 2011; O’Mahony \& Lakhany, 2011; Eseryel et al., 2020). It is the online environments provided by the diffusion of ICT that make it possible for members of a virtual community to have a common place to work, despite being dispersed

in time and space, so that they can share knowledge and create new and open collaborative products (Lee \& Cole, 2003; Li-Ying \& Salomo, 2013).

Free software projects are one of the most widespread domains in the study of community architecture, especially in literature on information systems and organizational studies, with the Linux operating system being one of the most famous cases (Demil \& Lecocq, 2006; Panchal, 2010; Grabher \& Ibert, 2014). These projects work in virtual communities, in which individuals or organizations open their programs with the purpose of receiving contributions from volunteers and heterogeneous software developers to solve problems or create new software products $(\mathrm{Li}$ \& Cole, 2003; Li, Yoo, \& Zang, 2016). Although research on free software is often cited as an example of an organization that represents the new generation of communities made possible by advances in ICT, this organizational format also extends to different domains (Seidel \& Stewart, 2011; Kolbjørnsrud, 2016). 


\subsection{Governance of Community-based Free Software Projects}

Although there are several studies that investigate community architecture (Shaikh \& Vaast, 2016), governance theory is still concentrated in the conventional model of organization, with hierarchical structure and processes marked by formalization (Child \& Rodrigues, 2003). In view of this reality, it is necessary that the discipline of governance be deepened in studies on virtual communities (O'Mahony \& Ferraro, 2007; Li-Ying \& Salomo, 2013), evidenced by a work organization that, even if different from the arrangements of more traditional ones, has operated in the production of high quality innovations (Lee \& Cole, 2003; Panchal, 2010; Miscione et al., 2018).

The governance approach in organizations, especially in the sphere of community arrangements, is somewhat complex and multidimensional, as it involves several elements such as the organizational and decision-making structure, the technical and management processes, and the property rights of the production carried out (Markus, 2007; Mäenpää et al., 2017; Glass \& Newig, 2019). Li-Ying and Salomo (2013) point out that the difficulty in understanding governance in community models comes from the divergences about which means of direction are appropriate to the different types of existing communities. In addition, governance itself is an intricate phenomenon in community projects (Markus, 2007) since these collectives have an open and distributed collaborative nature, in which heterogeneous individuals decide where, with whom, and in what to work, making it difficult to manage productive activities (Dahlander \& Wallin, 2006; Dahlander et al., 2008). Due to these issues, research on the topic is dispersed in several aspects, which makes it difficult to project governance in community groups (Li-Ying \& Salomo, 2013; Kolbjørnsrud, 2016).

Despite the challenge of achieving a common practical and theoretical understanding of governance in communities (Markus, 2007; Li-Ying \& Salomo, 2013), some definitions of the term are found in the literature in the field. Demil and Lecocq (2006) understand governance as an institutional framework that regulates transactions between community actors. For Markus (2007), governance is represented by the means used to achieve the direction and control of individuals in a community project. Based on the previous definitions, Li-Ying and Salomo (2013) conceive governance as a dynamic structure of formal and informal mechanisms that regulate the joint practices developed by the members of the communities in order to give rise to control.

The main purpose of governance mechanisms is to ensure the direction and control of individuals who integrate community environments (Demil \& Lecocq, 2006; Dahlander et al., 2008). Another issue related to governance concerns the perception that this concept is something dynamic and covers different organizational elements (Markus, 2007; O'Mahony \& Ferraro, 2007; Li-Ying \& Salomo, 2013). This work opted for understanding governance through two aspects: structural, which involves organizational design, roles, and project decisions (Demil \& Lecocq, 2006; Markus, 2007); and processual, which involves the control schemes employed in the dynamics of collaborative work (Child \& Rodrigues, 2003; Lattemann \& Steiglitz, 2005; Xu et al., 2005).

\subsection{Structure}

The structure constitutes the foundation on which all organizational mechanisms are based (Simeray, 1978) and provides the basis for people, resources, and tasks to be coordinated with a focus on achieving objectives (Mintzberg, 2011). The two basic types of structure found in organizations are the formal one, based on official labor relations, and the informal one, spontaneously arising from social interactions (Vasconcellos \& Hemsley, 2002; Mintzberg, 2011). 
The elements that make up the structure are represented by specialization, departmentalization, centralization, formalization, hierarchy, and breadth of control (Aldrich, 2007; Robbins, 2010). The combination of these types of structures and the variations between these elements allows different organizational formats to be established (Mintzberg, 2011). While traditional models exhibit a higher level of formalization, unity of command, high specialization, and vertical communication, more modern models have a lower degree of formalization, as well as low specialization and communication that does not depend on hierarchical levels (Vasconcellos \& Hemsley, 2002). Community projects are inserted in the scenario of modern typologies (Seidel \& Stewart, 2011; Li-Ying \& Salomo, 2013).

The definition of authority in community arrangements is not configured by the existence of a hierarchy (Aldrich, 2007; Robbins, 2010). In these arrangements, the work presents a horizontal perspective, which is defined by the establishment of lateral authority relations between the members of the group (Dahlander \& O’Mahony, 2011; Seidel \& Stewart, 2011). In lateral relationships, authority is a function of the abilities of individuals and noted by the decision rights or responsibilities they assume, becoming greater the closer these individuals are to the center of the community (Dahlander \& O’Mahony, 2011).

The ordering of work in the communities has some specificities since the adhesion of members to the projects depends heavily on voluntary work and, in these cases, an employment relationship is not established by a formal contract or financial remuneration (Lattemann \& Stieglitz; 2005; Shah, 2006; Seidel \& Stewart, 2011). Furthermore, community projects are based on open knowledge sharing, an indication that any individual can participate and have access to what is produced, as well as stop participating in the community (Lee \& Cole, 2003; Seidel \& Stewart, 2011). Because of this profile, the boundaries that define the contours of a community arrangement are fluid yet poorly defined (Faraj et al., 2011), so that the contributions of members tend to be weaker in the peripheral surroundings of the group and become stronger as they approach the central core, where the most active individuals with the most authority on the project are (Seidel \& Stewart, 2011).

Regarding the communication system of community projects, as its members are geographically distributed, ICT resources are essential to develop the group's collaborative and decision-making activities (Zheng et al., 2013; Hamersly, 2015; Eseryel et al., 2020). Among the resources that make up the technological infrastructure of the communities, we highlight the use of email lists, chat, video conferences, virtual groups, discussion forums, websites, bug trackers, and source code repositories, among others (Zhan et al., 2007; Seidel \& Stewart, 2011; Eseryel et al., 2020). The use of these resources reduces the information asymmetry in the communities and supports the transparency of the actions performed (Lattemann \& Stieglitz, 2005).

Regarding the definition of responsibilities, even if some roles are identified, the fact that the chain of command has a more informal and poorly defined character, especially when the members leave the core of the community (Seidel \& Stewart, 2011), makes individuals perform several functions and tasks that overlap (Faraj et al., 2011; Arazy et al., 2016). In this context, instead of formal work roles, emerging roles are commonly found in communities, which arise as work activities are established (Arazy et al., 2016). These are roles in which there is no planning or someone previously assigned to that specific function (Lee \& Cole, 2003), which demonstrates, in general, their low specialization in the communities. However, even though this mobility of roles exists at the individual level, the stability of work in community architecture is achieved by the fact that the collaborative activity is centered around the artifact produced (Arazy et al., 2016). 
One of the prominent roles that is normally well defined in the community environment is that of leadership, as their performance has a relevant impact on the success of projects in order to enable the construction of relationships, provide information about work, persuade people, and to assess team members (Druskat $\&$ Wheeler, 2003; Guimarães, Korn, Shin, \& Eisner, 2013; Mäenpää et al., 2017). It is the leadership that plays the most important role in controlling virtual community projects, making relevant decisions and implementing management strategies and practices that impact the project's performance and viability (Xu et al., 2005; Hamersly, 2015; Mäenpää et al., 2017).

\subsection{Control Processes}

The control processes identified in governance are carried out with the purpose of ensuring that heterogeneous individuals, whose objectives partially diverge, direct their behavior towards the achievement of organizational results (Ouchi, 1979; Das \& Teng, 1998). Various types of control are found in the literature on the subject.

Ouchi (1979) divides control into three mechanisms: 1) market mechanisms, which measure and remunerate individual contributions based on the results achieved; 2) the bureaucratic ones, which are centered on the hierarchy and the legitimation of the authority to control behaviors; and 3) clan members, whose core is the socialization of individuals for the convergence of objectives. Vilariño and Schoenherr (1987) divided control into three categories: 1) direct, practiced through order and express surveillance; 2) structural, involving technical and bureaucratic aspects; and 3) diffuse, based on cultural assumptions. Scott (1995), in turn, brought the following approaches to control: 1) regulatory, which uses a superficial and direct level when covering laws, sanctions, norms, and surveillance; 2) normative, which is backed by certification, through recognition and title; and 3) cognitive, which is based on cultural premises.

From the typologies exemplified, it is possible to see that control varies along two fundamental strands, that of formal and informal control mechanisms (Ouchi, 1979; Vilariño \& Schoenherr, 1987; Scott, 1995; Das \& Teng, 1998; Xu et al., 2005). Following this orientation, among the formal types of controls, there is the control of behavior and results. On the other hand, social control is an informal modality (Ouchi, 1979; Das \& Teng, 1998; Xu et al., 2005).

In the context of community projects, governance means are used, which aim to increase the commitment of the participants, acting not only on the motivation to contribute (Shah, 2006), but also in order to adapt the behaviors to the outlined objectives (Lattermann \& Stieglitz, 2005; Xu et al., 2005). In the course of these issues, the way of ensuring control in communities is made possible primarily through procedures with a more democratic and informal profile (O’Mahony \& Ferraro, 2007; Miscione et al., 2018), aimed at the socialization of individuals (Seidel \& Stewart, 2011), in contrast to the use of formal means which focus on behavior and results (Lattermann \& Stieglitz, 2005; Xu et al., 2005). However, it is relevant to emphasize that, even with the fluidity of community arrangements (Li et al., 2016), bureaucratic control procedures, such as the establishment of rules and norms, can also be used and combined with existing forms of social control (Markus, 2007; O'Mahony \& Ferraro, 2007; Chen \& O'Mahony, 2009, Mäenpää et al., 2017; Viseur \& Charleux, 2019). Xu et al. (2011) also noted the presence of results control in the study of free software communities, however, in a less formalized way than what happens in traditional teams.

Democratic control processes work through greater opportunity for members to participate in productive activities (German, 2003; O'Mahony \& Ferraro, 2007), as well as through the transparency of governance actions and the content developed in communities (Vincent \& Camp, 
2004; Markus, 2007). They depend on the existence of a context of meritocracy in projects that encourage quality contributions from members (O'Mahony \& Ferraro, 2007) through the recognition of technical and professional merit (Dahlander \& O’Mahony, 2011), status, assumed responsibilities, and opportunities to improve their own development (Stewart, 2005). Markus (2007) states that this democratic opening of communities also has a motivational character, which makes projects with this participatory and transparent format more successful in the mission of attracting employees.

Regarding socialization, it is noted, in community projects which use forms of control that promote the awareness of individuals, that they align their objectives with the purposes of the group (Lattermann \& Stieglitz, 2005; Xu et al., 2005). Based on the typologies of control exemplified, these mechanisms are founded upon the process of the intensive socialization of the members of the organization through the establishment of a shared culture (Xu et al., 2005; Seidel \& Stewart, 2011). They involve the promulgation of values, beliefs, and norms that must be internalized by the actors (Ouchi, 1979) and work as a collective contract to help the participants to understand the behaviors that are accepted and those that are not allowed in the communities (Xu et al., 2005; Li-Ying \& Salomo, 2013).

Seidel and Stewart (2011) affirm that this cultural control, reinforced by the interaction between the founders and the contributors on the projects, is critical for the maintenance and growth of the community arrangements. Through it, it is possible to strengthen cooperation between the actors in a group and promote the integration of heterogeneous people, who are distant from each other and who communicate mainly through the support of ICT (Lattermann \& Stieglitz, 2005; Zhan et al., 2007). Thus, the actions taken in the communities, in the absence of explicit contractual protection, take place around a common purpose (Dahlander $\&$ Wallin, 2006; O’Mahony \& Ferraro, 2007).

The culture established in the communities is consolidated through the shared practices built by the individuals during the performance of the collaborative work (Wenger, 1998). These practices are manifested through routines, symbols, stories, prototypes, rites, language, etc, which are part of the community's repertoire of representations (Wenger, 1998; Seidel \& O'Mahony, 2014). This shared repertoire of representations produces a reference among community members on how to interact, align work, and have a mutual understanding of the actions they perform (Okhuysen \& Bechky, 2009; Seidel \& O’Mahony, 2014). Furthermore, the sense of identification and belonging to the collective is strengthened (Seidel \& O'Mahony, 2014), especially when members are closer to the center of the group, which allows the definition of the group's limits and the consolidation of their identity (Wenger, 1998; Seidel \& Stewart, 2011).

In line with the direction given by social mechanisms, other forms of control verified in community projects are represented by peer control and self-control (Child \& Rodrigues, 2003; Arazy et al., 2016; Kolbjørnsrud, 2016). Peer control presupposes mutual adjustment of actors through interaction while performing certain tasks (Sutanto, Kankanhalli, \& Tan, 2011) and is mainly found in environments characterized by uncertainty about the ends and means, such as the case of community projects (Fjeldstad et al., 2012). Self-control refers to that modality in which the individual regulates himself in relation to the actions he performs (Lattermann \& Stieglitz, 2005; Kolbjørnsrud, 2016), having as antecedents the complexity of the task, the ambiguous evaluation of performance, and the lack of rules and procedures for completing a task (Xu et al., 2005).

\subsection{Overview of Governance: Traditional Organization vs. Community Organizations}


Chart 1, based on organizational and free software literature, summarizes the general and governance characteristics (structure and control) that have greater prevalence in community projects, compared to traditional organizations.

Chart 1

Comparison between traditional and community organizations

\begin{tabular}{|c|c|}
\hline Traditional organizations & Community organizations \\
\hline $\begin{array}{l}\text { Low adaptive flexibility } \\
\text { (Adler et al., 2011; Fjeldstad et al., 2012; } \\
\text { Zebari et al., 2019) }\end{array}$ & $\begin{array}{l}\text { High adaptive flexibility } \\
\text { (Adler et al., 2011; Faraj et al., 2011; Fjeldstad et al., } \\
\text { 2012; Zebari et al., 2019) }\end{array}$ \\
\hline $\begin{array}{l}\text { Confidentiality and commercial purpose } \\
\text { (Lee \& Cole, 2003; Chen \& O’Mahony, 2009; } \\
\text { Seidel \& Stewart, 2011; Miscione et al., 2018) }\end{array}$ & $\begin{array}{l}\text { Free creation and sharing of knowledge } \\
\text { (Lee \& Cole, 2003; Demil \& Lecocq, 2006; Seidel \& } \\
\text { Stewart, 2011; Miscione et al., 2018) }\end{array}$ \\
\hline $\begin{array}{l}\text { Dependent members in their choices to contribute } \\
\text { (Seidel \& Stewart, 2011; Lindberg et al., 2016) }\end{array}$ & $\begin{array}{l}\text { Independent members in their choices to contribute, } \\
\text { but with interdependent production } \\
\text { (Seidel \& Stewart, 2011; Lindberg et al., 2016; } \\
\text { Kolbjørnsrud, 2016) }\end{array}$ \\
\hline $\begin{array}{l}\text { Hierarchical and with formal authority } \\
\text { (Lee \& Cole, 2003; Demil \& Lecocq, 2006; Seidel } \\
\text { \& Stewart, 2011; Arazy et al., 2016; Lindberg et al., } \\
\text { 2016) }\end{array}$ & $\begin{array}{l}\text { Horizontal and with lateral authority } \\
\text { (Panchal, 2010; Dahlander \& O’Mahony, 2011; } \\
\text { O’Mahony \& Lakhany, 2011; Seidel \& Stewart, } \\
\text { 2011) }\end{array}$ \\
\hline $\begin{array}{l}\text { Well-defined organizational and } \\
\text { decision-making structure } \\
\text { (Vasconcellos \& Hemsley, 2002; Mintzberg, 2011; } \\
\text { Demil \& Lecocq, 2006; Lindberg et al., 2016) }\end{array}$ & $\begin{array}{l}\text { Poorly defined organizational and decision-making } \\
\text { structure, with strong leadership } \\
\text { (Seidel \& Stewart, 2011; Arazy et al., 2016; Lindberg } \\
\text { et al., 2016; Guimarães, 2013; Mäenpää et al., 2017) }\end{array}$ \\
\hline $\begin{array}{l}\text { Well-established boundaries } \\
\text { (Child \& Rodrigues, 2003; Lee \& Cole, 2003; } \\
\text { Chen \& O’Mahony, 2009) }\end{array}$ & $\begin{array}{l}\text { Fluid boundaries, with permeable boundaries } \\
\text { of adhesion } \\
\text { (Faraj et al., 2011; Seidel \& Stewart, 2011; Li et al., } \\
\text { 2016) }\end{array}$ \\
\hline $\begin{array}{l}\text { Work formalized by contracts and remuneration } \\
\text { (Lattermann \& Stieglitz, 2005; Dahlander \& Wallin, } \\
\text { 2006; O’Mahony \& Ferraro, 2007) }\end{array}$ & $\begin{array}{l}\text { Significant incorporation of voluntary work } \\
\text { (Shah, 2006; Seidel \& Stewart, 2011; Lindberg et al., } \\
\text { 2016) }\end{array}$ \\
\hline $\begin{array}{l}\text { Physical and technological infrastructure } \\
\text { (Lee \& Cole, 2003; O’Mahony \& Lakhany, 2011; } \\
\text { Seidel \& Stewart, 2011) }\end{array}$ & $\begin{array}{l}\text { Essentially technological infrastructure } \\
\text { (Lee \& Cole, 2003; Seidel \& Stewart, 2011; } \\
\text { Zheng et al., 2013) }\end{array}$ \\
\hline $\begin{array}{l}\text { Control with a more formal and bureaucratic profile } \\
\text { (O'Mahony \& Ferraro, 2007; O’Mahony \& Lakhany, } \\
\text { 2011; Seidel \& Stewart, 2011; Arazy et al., 2016) }\end{array}$ & $\begin{array}{l}\text { Control with a more informal and democratic } \\
\text { profile, strong presence of meritocracy } \\
\text { (O'Mahony \& Ferraro, 2007; Panchal, 2010; } \\
\text { Arazy et al., 2016; Miscione et al., 2018) }\end{array}$ \\
\hline $\begin{array}{l}\text { Behavioral control, output control } \\
\text { (Lattemann \& Steiglitz, 2005; Xu et al., 2005; } \\
\text { Markus, 2007) }\end{array}$ & $\begin{array}{l}\text { Social control, peer control, and self-control } \\
\text { (Lattemann \& Steiglitz, 2005; Xu et al., 2005; } \\
\text { Kolbjørnsrud, 2016) }\end{array}$ \\
\hline
\end{tabular}

Source: Based on literature review (2020). 


\subsection{Methodological Procedures Used in Exploratory Research}

Exploratory and descriptive research was carried out with qualitative guidance, in which documents were accessed and interviews were conducted with four Brazilian members participating in the management of different community-based free software projects. It is important to note that this exploratory research aimed to bring a complementary understanding in addition to that brought forth through the literature in the area. It was not intended to be in-depth qualitative research, but one that enabled researchers to understand more about these projects from a practical perspective. It was, therefore, a first contact with the field of investigation, which helped to add knowledge beyond the literature, as well as contributing more robust reflections on the topic, thus providing a foundation for future research. This justifies the small number of study participants and the descriptive character of the analyses.

To gain access to the interviewees, the researchers used not only the information provided by professors and professionals in the free software area of their network of contacts, but also carried out documentary research on the websites of events that took place in Brazil. Among these events were the Free Software Technology Forum, the Free Software International Forum, and the Free Software Goiano Forum. With this mapping, it was possible to obtain the e-mail addresses of individuals participating in different projects; through the contacts previously established, four of them accepted to participate in the research conducted through interviews.

The four community-based free software projects were represented by the letters W, X, Y, and $Z$. For the interviews, a semi-structured questionnaire was used, with questions broad enough to obtain information about the general and governance characteristics of the projects. The dimensions of analysis focused on obtaining the interviewees' perceptions about the dynamics of functioning and the aspects of governance involved as a result of the structure and control processes observed in the collectives. Chart 2 shows the relationship between the dimensions of analysis of the research and the questions that comprised the interview script.

Each interview lasted about 60 minutes and was recorded and transcribed later. Documentary research was conducted on the websites of the investigated projects with the intention of complementing the information obtained in the interviews. The analysis of the collected data was made possible through the content analysis technique (Bardin, 2010; Krippendorff, 2013) according to the analysis dimensions previously established.

\subsection{Description of the Main Perceptions Observed in the Exploratory Research}

The interviews and analysis of the documents allowed the researchers to outline the main attributes of governance, in structural and control terms, of the four community projects in which the interviewees belonged. All projects had the source code available on their own free software platform (project W) or on GitHub (other projects). General information about the project and the license used was found on the projects' platforms and websites. The general characteristics of each of the investigated projects are described in Chart 3. 
Chart 2

Research analysis dimensions associated with interview script questions

\begin{tabular}{|c|c|c|c|}
\hline \multicolumn{3}{|c|}{ Analysis dimensions } & Questions \\
\hline \multirow{10}{*}{ Governance } & \multirow{2}{*}{\multicolumn{2}{|c|}{ General aspects }} & $\begin{array}{l}\text { 1) How did the project come about? Talk about the history and your } \\
\text { performance within the project. }\end{array}$ \\
\hline & & & $\begin{array}{l}\text { 2) How is the project managed and sustained in terms of resources } \\
\text { and infrastructure necessary for its operation? }\end{array}$ \\
\hline & & Hierarchy & $\begin{array}{l}\text { 3) Is there a hierarchy among the members who work on the project? } \\
\text { Explain how this hierarchy plays out. }\end{array}$ \\
\hline & Structure & Papers & $\begin{array}{l}\text { 4) How does the division of roles between project members happen? } \\
\text { Identify the main existing roles. }\end{array}$ \\
\hline & & Decisions & 5) How are the decisions made in the project? \\
\hline & \multirow{5}{*}{ Control } & Formal & $\begin{array}{l}\text { 6) Does the project have rules, standards, or other procedures for } \\
\text { carrying out activities? Specify these procedures. }\end{array}$ \\
\hline & & \multirow{4}{*}{$\begin{array}{l}\text { Informal } \\
\text { (social, peer } \\
\text { and self- } \\
\text { control) }\end{array}$} & $\begin{array}{l}\text { 7) Does the project usually hold meetings and events (in person or } \\
\text { virtual)? How do these meetings take place? }\end{array}$ \\
\hline & & & $\begin{array}{l}\text { 8) How does the project promote the recognition of contributions } \\
\text { made by members? }\end{array}$ \\
\hline & & & $\begin{array}{l}\text { 9) How are errors or needs for software improvement identified in the } \\
\text { project? }\end{array}$ \\
\hline & & & $\begin{array}{l}\text { 10) Is there autonomy in carrying out the work developed in the } \\
\text { project? Detail how this autonomy plays out. }\end{array}$ \\
\hline
\end{tabular}

Source: Based on literature review (2020).

Chart 3

General characteristics of community-based free software projects

\begin{tabular}{|c|c|c|l|}
\hline $\begin{array}{c}\text { Community } \\
\text { project }\end{array}$ & $\begin{array}{c}\text { Year of } \\
\text { appearance }\end{array}$ & Performance level & \multicolumn{1}{|c|}{ Scope } \\
\hline W & 2010 & Global & Office application suite \\
\hline X & 2003 & Global & Free software for Internet content management \\
\hline Y & 2007 & National & Web platform aimed at creating social networks \\
\hline Z & 2013 & National & Chat platform for web, desktop, and mobile \\
\hline
\end{tabular}

Source: Based on interviews and documentary research (2020).

The W and X projects are "fork", that is, they are branches of other previously existing free software initiatives. Both have communities consisting of different nationalities, with interviewees who are members of Brazilian communities. Another characteristic of the projects is that they have foundations in their governance. Foundations are characterized by being non-profit entities that perform the administrative management of the enterprise with the purpose of guaranteeing the quality of the software produced. In project W, the foundation was created concurrently with the start of the collective, while in project $\mathrm{X}$, the foundation was in operation seven years after the start of this project.

The $\mathrm{Y}$ and $\mathrm{Z}$ projects, in turn, are Brazilian free software initiatives that, unlike the two previous projects, do not have segmented communities in different countries nor the support of foundations in their management. However, they are collectives that group individuals of 
different nationalities and which also have organizational ties. As reported by the interviewees, while Project $Y$ was born as part of a cooperative focused on the production of free software solutions, Project $\mathrm{Z}$ was created in a private corporate context and only later became free software.

In general, it was noted that in the structure of each of the investigated projects, a relationship with some organization resulted, be it a foundation, cooperative, or private company. According to the interviewees, each of these organizations has its own way of structuring and controlling its administrative routines that occur in a context of formal work relationships. Through the interviews, it was possible to understand that such organizations play a crucial role in the governance of the projects to which they are linked, especially in ensuring the quality of software, as well as in attracting and providing the physical, technological, and financial resources necessary for the productive activities.

In parallel with the formal structure of the organizations, the interviewees reported that the projects have their communities functioning. In the $\mathrm{W}$ and $\mathrm{X}$ projects, it was found that, although the communities have a certain autonomy to operate, the actions carried out must be in accordance with the guidelines provided by their respective foundations. Thus, even if the projects have communities formed by members who are geographically dispersed and with intense participation of volunteers, the joint production of individuals needs to have alignment with the guidelines provided by the foundations. The same situation was noticed in the communities of projects $\mathrm{Y}$ and $\mathrm{Z}$ since there is a dependent relationship between these structures, the cooperative, and the company that created these initiatives. In this regard, it was noted that the fact that these organizations have employment contracts that provide financial gains with the support and customization of the software makes them exert influence on the community production process. In view of this, even though the program is openly available to receive contributions, in practice, community management takes place, above all, through the performance of members belonging to these organizations. That said, it was possible to verify that for the understanding of any of the projects (W, X, Y, Z), it is inevitable to consider the influence exerted by the formal organizations with which the respective communities relate.

Specifically considering the dynamics of the communities, through the interviews, it was found that formalization of structure and control take place at certain times to ensure the management of decentralized actions around the software. Regarding the hierarchy, all respondents reported that it is common for actions developed within communities to have a leader or person in charge who manages and makes the necessary decisions. In the W and X projects, leadership is exercised notably by the most active members of the Brazilian communities. The interviewee of the W project, due to the proactive role assumed in the collective, was invited to become a member of the foundation that governs this project. In projects $\mathrm{Y}$ and $\mathrm{Z}$, the members most frequently involved in the management of activities coincided with those belonging to the organizations that started the project. In addition to this formal leadership that assumes the management of certain project initiatives, the interviewees reported that, within the communities, there is also an informal hierarchy, which is the result of the merit and knowledge that individuals have about the project.

Regarding the performed roles, respondents demonstrated assistance to their communities mainly through the following activities: promotion of software dissemination events, support of the releases of versions of software development of software source code, updated sites, elaboration of answers to questions from discussion forums and e-mails, translation of documents, etc. All 
interviewees reported that, in addition to being perceived in projects in which the role of leadership acts on different fronts, there is also the role of committer, represented by the member with access and writing power in the software source code repository. Project $Y$, in particular, found the role of the release manager, performed by the member of the community responsible for the release of the software versions. It was also reported in the interviews that although some roles are defined, community participants are not necessarily limited to the exercise of a single function since they can participate in multiple activities concomitantly, according to their interests.

In terms of decisions, project members reported that it is common to seek consensus and the participation of members in the choices made by the communities. However, when the decisions are of a strategic level and have an impact on the quality of the software, the interviewees stressed that decision-making can take place in a formal way, involving voting and counting on the effective participation of the organizations that act in the governance of the projects.

With regard to control, it was noted in the interviews that despite the informal aspects, some formalities took place in the collectives. These formalizations appeared to be especially linked to the project's core processes, such as the release of software versions, as well as the interfaces between communities and organizations with which they relate.

In the interviews, it was reported that there are rules for contributions to be incorporated into the source code, so that they must necessarily go through the review of some other member. Respondents from the W and X projects reported that the rules and regulations developed by the foundations guide and affect the activities of the communities. Another moment in the interviews in which formal control was highlighted was associated with the relationships between the communities and the organizations with which they are linked, which proved to be essential for raising funds for the project. Regarding this, in the W and X projects, the receipt of donations from companies whose mediation occurs through the foundations was mentioned. In project Y, the interviewee reported that the parallel projects developed with other organizations allow the cooperative to have financial gains to invest in the software community. In Project $Z$, the interviewee reported the receipt of an American investment fund, which provided for acquisitions by the company that manages the software, also brought improvements to the project community. In the foundations, cooperatives and private companies that participate in the governance of the projects, it was observed that there are paid professionals who simultaneously integrate the organization and the project community, coinciding with the volunteer participants.

In the informal aspects, the projects showed concern with the socialization of the members, in regards to developing a sense of belonging to the collective. Respondents from the W and $\mathrm{X}$ projects pointed out that they usually organize open events to promote interaction between people, as well as to promote the dissemination of the software. Respondents from $\mathrm{Y}$ and $\mathrm{Z}$ projects reported that community members often participate in interviews, academic events, or in the free software areas to discuss the project. All of these socialization paths mean that even members who are geographically distant, or who have greater autonomy because they are volunteers, align their behaviors with the objectives of the project. Socialization seemed to be a mechanism, therefore, that influences self-control, especially for volunteer members who have greater freedom of action in the activities performed. Another form of informal control verified in the projects was the peer control, because even when a member assumes the role of committer, the review of the source code by another participant of the group before it is inserted in the project repository is common. 


\section{REFLECTIONS ON COMMUNITY-BASED}

\section{FREE SOFTWARE PROJECTS}

Through the comparisons between the way the literature usually approaches communitybased free software projects and the perceptions achieved through exploratory research, some reflections were outlined.

When portraying the development of community projects, studies in the area usually state that governance processes are dynamic and can be established, adjusted, or abandoned as needed. As a result of this dynamism, variations of the communities are found depending on the complexity and the growth achieved (Xu et al., 2005; Forte, Larco, \& Bruckman, 2009; Li-Ying \& Salomo, 2013; Mäenpää et al., 2017; Viseur \& Charleux, 2019). Converging with these views, the interviews brought the perception that although there are similarities, the projects investigated had different development trajectories, seen as fundamental to explain the current configuration of their governance. Thus, governance has proved to be a flexible phenomenon and adaptable to situations that have occurred throughout history, which brings particular characteristics to collectives. As an example of this situation, it is possible to mention the context in which the projects operate. Although the W and X groupings are "fork", their respective foundations were created at different times, according to the needs of each of these projects. Project $Y$ originated in the context of a cooperative, while $\mathrm{Z}$ from the beginning was linked to a private company, but only later did it become a free software initiative.

To this day, research on community-based free software projects continues trying to differentiate their governance from so-called traditional organizations (Miscione et al., 2018). Based on the studies of Raymond (1999; 2005), while communities are seen as "bazaar" arrangements with an open exchange of knowledge and informal configuration, traditional organizations approach a "cathedral" architecture, with structure and processes that formalize control procedures. In practice, however, the interviewees' report found that formalizations took place, especially in the relationships established between the projects and the organizations with which they are linked, or even with other external organizations, mainly those focused on obtaining resources. Within the community, specifically, formalizations took place mainly to guarantee the quality of the software. Among the examples of formal situations seen in the communities, the following stand out: the definitions of roles; centralizing the project's most strategic decisions; the control processes directed to the production; and dissemination of the software.

Although certain authors recognize that community-based free software projects in the course of their development can be formalized, managed, or sponsored by other organizations (West \& O’Mahony, 2005; Panchal, 2010; Li-Ying \& Salomo, 2013; Mäenpää et al., 2017; Viseur \& Charleux, 2019), the understanding of how this happens remains relatively unexplored empirically. This fact is visible when projects in advanced stages of maturity, such as Linux, Apache, Gnome, among others, are cited as examples of community initiatives (Lee \& Cole, 2003, Shah, 2006; Seidel \& Stewart, 2011; Lindberg et al., 2016), without deepening the transformations that led to the current configuration of these structures.

It is necessary to consider that there is a diversity of community projects on the Internet, involving both communities that do not have many contributors besides their initial founders, and those that have lost their popularity over time, even communities in an advanced stage of development (Stewart \& Gosain, 2006; Seidel \& Stewart, 2011). As a result, and as perceived in exploratory research, research on the governance of community projects, such as free software initiatives, needs to address the issue from a broader perspective. In this perspective, community 
projects must be understood considering the changes they have undergone in the course of their development, as well as the context in which they are inserted. This context involves not only the community arrangement itself, but also the relationships established with other organizations and which influence the functioning of these communities. Thus, it avoids that projects of the most diverse types are portrayed as representatives of the community model, or as opposed to traditional organizations, without sufficient contextualization in this sense. Figure 1 summarizes the central idea brought up in the paper.

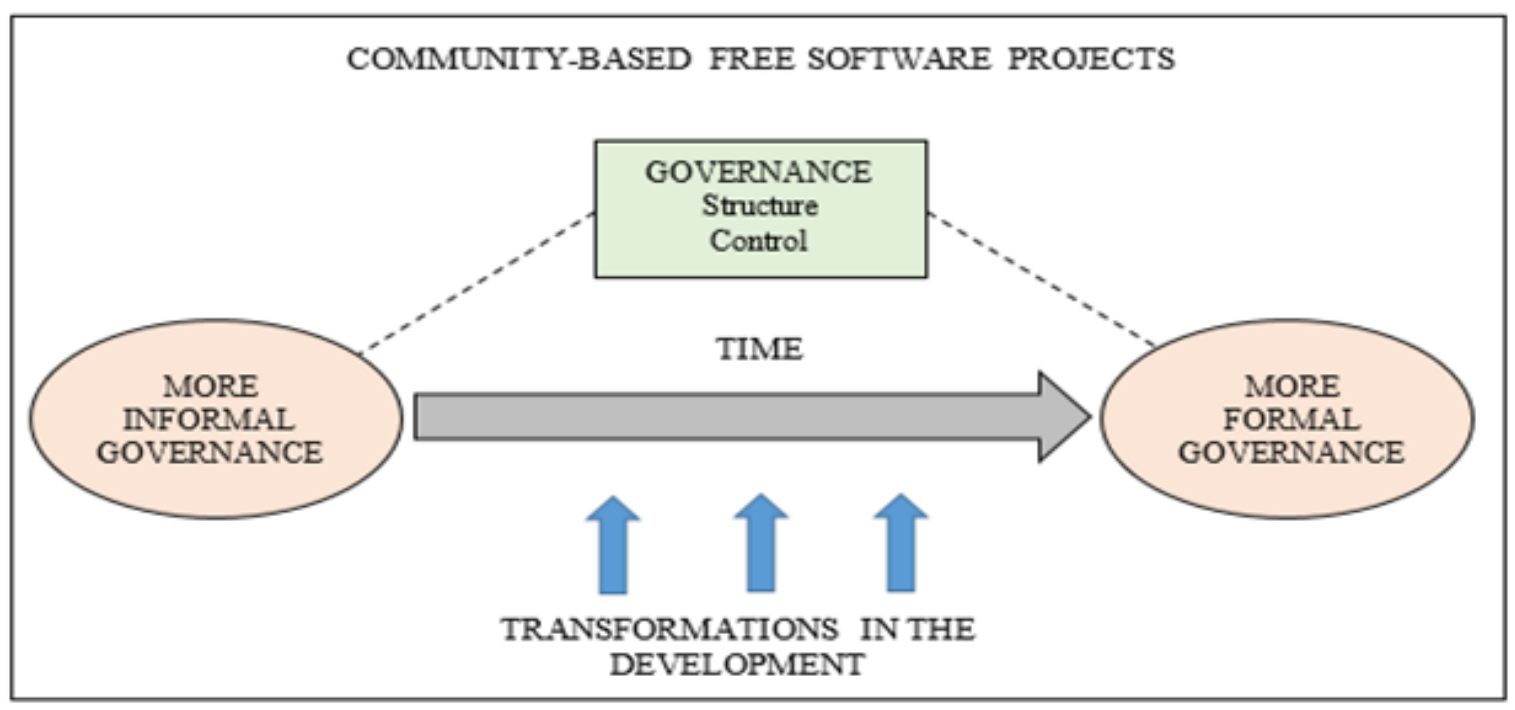

Figure 1. Governance transformations in the development of community projects.

Source: Based on literature review (2020).

\section{CONCLUSIONS}

The results achieved from the literature and exploratory research allowed us to note that the governance of free software communities has not proved to be something rigid and definitive. On the contrary, it constituted a dynamic framework, with flexible contours and strong adaptability to the environment and the evolution of the project (Lattermann \& Stieglitz, 2005; Xu et al., 2005; Crowston et al., 2007; Panchal, 2010; Li-Ying \& Salomo, 2013; Mäenpää et al., 2017; Viseur \& Charleux, 2019).

Although the developmental aspect is crucial for the study of governance and recognized by some authors (Lattermann \& Stieglitz, 2005; Xu et al., 2005; Panchal, 2010; Guimarães et al., 2013; Mäenpää et al., 2017; Viseur \& Charleux, 2019), it is not always discussed in detail in empirical research. Therefore, it is common for successful free software projects to be investigated as arrangements that follow the community logic, in contrast to traditional organizations, without, as in a significant part of the cases, being concerned with debating the temporal and maturing circumstances in which they meet. Projects such as those observed in exploratory research, which emerged at the organizational level and/or established interorganizational relationships, for example, presented formalizations of the structure and the control processes in conjunction 
with the informality typical of community initiatives. This fact demonstrates the complexity of governance in the context of the scenario examined since the community is an integral part of an environment that has mutually influenced it over time.

Although didactically and theoretically it is possible to trace the governance characteristics that differentiate community free software ventures from traditional organizations, in practice, the reality may not happen that way. Therefore, bringing approaches that involve the transformations experienced by the projects, considering the context in which the community is inserted and the interfaces with other organizations, allows the presentation of more realistic views on the topic. The making of contributions in this sense will be fundamental for the careful positioning of community arrangements in organizational research, especially with regard to the dichotomy between communities versus traditional organizations. Although the study of governance in communities is still somewhat controversial, and there is no consensus in the literature, the results achieved here allow us to observe that some free software projects, due to the characteristics presented, can operate in a manner close to that of traditional organizations, even if they maintain community traits.

Having made these considerations, it is expected that future studies will bring new knowledge that complements the perspectives discussed in this article. Such ideas, once put into practice, not only in the area of free software, but also in other types of communities, would allow clarification if the transformations experienced by the collectives that present a growth trajectory approach the typical constitutions of traditional organizations, or if they continue preserving, in different degrees, their original community values. The approach to these issues, in the theoretical and empirical field, would fill important gaps about the changes in the attributes of governance that may have occurred, from the emergence of the group to its current or more advanced stage of development.

It is possible to see in the conclusions presented that there was a concern in this paper to bring contributions to researchers who intend to deepen their understanding of community-based free software projects. These projects deserve an even greater role in the scenario of organizational studies as they are already well consolidated in the area of information systems. This fact is justified by the complexity of the community model and its importance in the software industry, acting in the development of innovative and competitive products, as well as traditional technology companies. It is emphasized that this work has the limitation of being preliminary research and focusing on the proposition of reflections. The idea of the article is to demonstrate that the field of free software can allow advances in the understanding of the community model of production, going beyond the commonly held view, which highlights that the structure and control processes of these businesses work through informal governance.

\section{REFERENCES}

Adler, P., Heckscher, C., \& Prusak, L. (2011). Cómo construir una empresa colaborativa: cuatro claves para crear una cultura de confianza y trabajo en equipo. Harvard Business Review, 89(6), 44-52.

Aldrich, H. E. (2007). Organizations and environments. Stanford: Stanford University Press.

Arazy, O., Daxenberger, J., Lifshitz-Assaf, H., Nov, O., \& Gurevych, I. (2016). Turbulent stability of emergent roles: The dualistic nature of self-organizing knowledge coproduction. Information Systems Research, 27(4), 792-812. 
Bardin, L. (2010). Análise de Conteúdo. Lisboa: Edições 70.

Chen, K. K., \& O’Mahony, S. (2009). Differentiating organizational boundaries. In B. G. King, T. Felin, \& D. A. Whetten (Eds.). Studying Differences Between Organizations: Comparative Approaches to Organizational Research, Research in the Sociology of Organizations. Bingley: Emerald Group Publishing Limited, 183-220.

Child, J., \& Rodrigues, S. B. (2003). Corporate governance and new organizational forms: Issues of double and multiple agency. Journal of Management and Governance, 7(4), 337-360.

Crowston, K., Wei, K., Li, Q., Eseryel, Y., \& Howison, J. (2007). Self-organization of teams in free/libre open source software development. Information and Software Technology Journal, 49(6), 564-575.

Dahlander, L., \& O’Mahony, S. (2011). Progressing to the center: Coordinating project work. Organization Science, 22(4), 961-979.

Dahlander, L., \& Wallin, M. W. (2006). A man on the inside: Unlocking communities as complementary assets. Research Policy, 35(8), 1243-1259.

Dahlander, L., Frederiksen, L., \& Rullani, F. (2008). Online communities and open innovation. Industry and Innovation, 15(2), 115-123.

Das, T. K., \& Teng, B. S. (1998). Between trust and control: Developing confidence in partner cooperation in alliances. Academy of Management Review, 23(3), 491-512.

Demil, B., \& Lecocq, X. (2006). Neither market nor hierarchy nor network: The emergence of bazaar governance. Organization Studies, 27(10), 1447-1466.

Druskat, V. U., \& Wheeler, J. V. (2003). Managing from the boundary: The effective leadership of self-managing work teams. Academy of Management Journal, 46(4), 435-457.

Eseryel, U. Y., Wei, K., \& Crowston, K. (2020). Decision-making Processes in Community-based Free/Libre Open Source Software-development Teams with Internal Governance: An Extension to Decision-making Theory. Communications of the Association for Information Systems, 46(1), 20.

Faraj, S., Jarvenpaa, S. L., \& Majchrzak, A. (2011). Knowledge collaboration in online communities. Organization Science, 22(5), 1224-1239.

Fjeldstad, Ø. D., Snow, C. C., Miles, R. E., \& Lettl, C. (2012). The architecture of collaboration. Strategic Management Journal, 33(6), 734-750.

Forte, A., Larco, V., \& Bruckman, A. (2009). Decentralization in Wikipedia governance, Journal of Management Information Systems, 26(1), 49-72.

German, D. M. (2003). The GNOME project: A case study of open source, global software development. Software Process Improvement and Practice, 8(4), 201-215.

Glass, L. M., \& Newig, J. (2019). Governance for achieving the Sustainable Development Goals: How important are participation, policy coherence, reflexivity, adaptation and democratic institutions? Earth System Governance, 2, 1-14.

Grabher, G., \& Ibert, O. (2014). Distance as asset? Knowledge collaboration in hybrid virtual communities. Journal of Economic Geography, 14(1), 97-123.

Guimarães, A. L., Korn, H. J., Shin, N., \& Eisner, A. B. (2013). The life cycle of open source software development communities. Journal of Electronic Commerce Research, 14(2), 167-182. 
Hamersly, W. J. (2015). Business governance best practices of virtual project teams. Doctoral dissertation, Walden University, Minneapolis, Minnesota, United States.

Kolbjørnsrud, V. (2016). Agency problems and governance mechanisms in collaborative communities. Strategic Organization, Special Issue Article, 1-36.

Krippendorff, K. (2013). Content Analysis. An Introduction to Its Methodology. Sage, London.

Lattemann, C., \& Stieglitz, S. (2005). Framework for governance in open source communities. Proceedings of the HICSS, Hawaii, 192-201.

Lee, G. K., \& Cole, R. E. (2003). From a firm-based to a community-based model of knowledge creation: The case of the Linux kernel development. Organization Science, 14(6), 633-649.

Li, X., Yoo, Y., \& Zhang, Z. (2016). Searching for "Stability" in Fluidity: A Routine-based View of Open Source Software Development Process. Proceedings of the ICIS, Dublin.

Lindberg, A., Berente, N., Gaskin, J., \& Lyytinen, K. (2016). Coordinating interdependencies in online communities: A study of an open source software project. Information Systems Research, 27(4), 751-772.

Li-Ying, J., \& Salomo, S. R. (2013). Design of governance in virtual communities: definition, mechanisms, and variation patterns. International Journal of Collaborative Enterprise, 3(4), 225-251.

Mäenpää, H., Munezero, M., Fagerholm, F., \& Mikkonen, T. (2017, August). The many hats and the broken binoculars: State of the practice in developer community management. Proceedings of the OpenSym, Galway, 1-9.

Markus, M. L. (2007). The governance of free/open source software projects: monolithic, multidimensional, or configurational? Journal of Management \& Governance, 11(2), 151-163.

Mintzberg, H. (2011). Criando organizaçôes eficazes: estrutura em cinco configuraçôes. São Paulo: Atlas.

Miscione, G., Ziolkowski, R., Zavolokina, L., \& Schwabe, G. (2018, September). Tribal governance: The business of blockchain authentication. Proceedings of the HICSS, Hawaii, 1-10.

O’Mahony, S., \& Ferraro, F. (2007). The Emergence of Governance in an Open Source Community. Academy of Management Journal, 50(5), 1079-1106.

O’Mahony, S., \& Lakhani, K. R. (2011). Organizations in the shadow of communities. In C. Marquis, M. Lounsbury, R. Greenwood (Eds.). Communities and Organizations, Research in the Sociology of Organizations. Bingley: Emerald Group Publishing Limited, 3-36.

Okhuysen, G. A., \& Bechky, B. A. (2009). 10 coordination in organizations: An integrative perspective. The Academy of Management Annals, 3(1), 463-502.

O’Mahony, S., \& Lakhani, K. R. (2011). Organizations in the shadow of communities. In C. Marquis, M. Lounsbury, R. Greenwood (Eds.). Communities and Organizations, Research in the Sociology of Organizations. Bingley: Emerald Group Publishing Limited, 3-36.

Ouchi, W. G. (1979). A Conceptual Framework for the Design of Organizational Control Mechanisms. Management Science, 25(9), 833-848.

Panchal, J. H. (2010). Coordination in collective product innovation. Proceedings of the ASME, Vancouver, 333-346.

Raymond, E. (1999). The cathedral and the bazaar. Knowledge, Technology \& Policy, 12(3), 23-49.

Raymond, E. (2005). The cathedral and the bazaar (originally published in volume 3, number 3, march 1998). First Monday. 
Robbins, S. P. (2010). Organizational Behavior. Pearson Education.

Santos junior, C. D.; Kuk, G.; Kon, F.; Suguiura, R. (2011). The inextricable role of organizational sponsorship for open source sustainability. Proceedings of SOS.

Santos, C., Kuk, G., Kon, F., \& Pearson, J (2013). The attraction of contributors in free and open source software projects. Journal of Strategic Information Systems, 22, 26-45.

Scott, W. R. (1995). Institutions and organization. Thousand Oaks: Sage Publications.

Seidel, M. D. L., \& Stewart, K. J. (2011). An initial description of the C-form. In C. Marquis, M. Lounsbury, \& R. Greenwood (Eds.). Communities and Organizations, Research in the Sociology of Organizations. Bingley: Emerald Group Publishing Limited, 37-72.

Seidel, V. P., \& O’Mahony, S. (2014). Managing the Repertoire: Stories, Metaphors, Prototypes, and Concept Coherence in Product Innovation. Organization Science, 25(3), 691-712.

Shah, S. K. (2006). Motivation, governance, and the viability of hybrid forms in open source software development. Management Science, 52(7), 1000-1014.

Shaikh, M., \& Vaast, E. (2016). Folding and unfolding: balancing openness and transparency in open source communities. Information Systems Research, 27(4), 813-833.

Simeray, J. P. (1978). A estrutura da empresa. Rio de Janeiro: LTC.

Stewart, D. (2005). Social status in an open-source community. American Sociological Review, 70(5), 823-842.

Stewart, K. J., \& Gosain, S. (2006). The moderating role of development stage in free/open source software project performance. Software Process: Improvement and Practice, 11(2), 177-191.

Sutanto, J., Kankanhalli, A., \& Tan, B. C. (2011). Deriving IT-mediated task coordination portfolios for global virtual teams. IEEE Transactions on Professional Communication, 54(2), 133-151.

Vasconcellos, E., \& Hemsley, J. R. (2002). Estrutura das organizações. São Paulo: Thomson Pioneira Learning.

Vilariño, J. P., \& Schoenherr, R. A. (1987). Racionalidad y control en las organizaciones complejas. Reis, 39, 119-139.

Vincent, C., and Camp, J. (2004). Looking to the Internet for models of governance. Ethics and Information Technology, 6(3), 161-173.

Viseur, R., \& Charleux, A. (2019). Changement de gouvernance et communautés open source: le cas du logiciel Claroline. Innovations, (1), 71-104.

Wenger, E. (1998). Communities of practice. Learning, meaning and identity. Cambridge: Cambridge University Press.

West, J., \& O’Mahony, S. (2005). Contrasting community building in sponsored and community founded open source projects. Proceedings of the HICSS, Hawaii, 196c.

$\mathrm{Xu}$, B., Lin, Z.; Xu, Y. (2011). A study of open source software development from control perspective. Journal of Database Management, 22(1), 26-42.

$\mathrm{Xu}, \mathrm{B} ., \mathrm{Xu}, \mathrm{Y}$., \& Lin, Z. (2005). Control in open source software development. Proceedings of the AMCIS, Omaha, 433.

Zhan, Y., Bai, Y., \& Liu, Z. (2007). Virtual Team Governance: Addressing the Governance Mechanisms and Virtual Team Performance. In W. Wang, Y. Li, Z. Duan, L. Yan, H. Li, and X. Yang. (Ed). Integration and Innovation Orient to E-Society. Boston: Springer, 282-288. 
BBR

18

352

Zheng, Y., Zhao, K., \& Stylianou, A. (2013). The impacts of information quality and system quality on users' continuance intention in information-exchange virtual communities: An empirical investigation. Decision Support Systems, 56, 513-524.

Raymond, E. (2005). The cathedral and the bazaar (originally published in volume 3, number 3, march 1998). First Monday.

Zebari, R. R., Zeebaree, S. R., Jacksi, K., \& Shukur, H. M. (2019). E-business requirements for flexibility and implementation enterprise system: A review. International Journal of Scientific and Technology Research, 8(11), 655-660.

\section{AUTHOR'S CONTRIBUTION}

All authors contributed to the design of the study. The main researcher participated in the elaboration of the research and data analysis. The other researcher participated in guiding the entire process of searching and revising the text, making any necessary adjustments.

\section{ACKNOWLEDGEMENT}

Research developed partially with the support of CAPES (process 88881.173270/2018-01), and the LATECE laboratory (Université du Québec à Montreal - UQAM).

\section{CONFLICTS OF INTEREST}

There are no conflicts of interest in this article or during its elaboration. 